\title{
HISTÓRIA, LINGUAGEM E LITERATURA: \\ Dilemas e Perspectivas da Historiografia Contemporânea
}

\author{
History, Language and Literature: \\ Quandaries and Perspectives of the Contemporary Historiography
}

Diogo Cesar Nunes*

\begin{abstract}
RESUMO:
Nos últimos anos, a "crise da História" se tornou um destacado tema da historiografia contemporânea. Causada ou pelo "refluxo" do materialismo e do estruturalismo, ou pelo "retorno da literatura", no cerne da crise encontram-se novas noções de realidade histórica e de cultura que, animadas pelo pós-estruturalismo, pela "virada linguística" e por uma maior aproximação com a filosofia, a literatura, a psicologia, questionam paradigmas da História Social. O presente trabalho pretende, assim, apontar algumas destas questões para pensar como a crítica ao contextualismo e a apologia da interpretação provocam uma revisão não somente metodológica, mas ontológica da História. Outrossim, explora possibilidades teóricas que, com esta revisão, possam aproximar História e Literatura não mais, como diz David Harlan, para promover um retorno de escritores antigos a seus contextos históricos mas para que "trabalhos valiosos do passado" sobrevivam a seu tempo "de modo a falar-nos sobre nosso presente".

Palavras-Chave: Historiografia; História intelectual; "Virada linguística”; História cultural; Literatura; Hermenêutica.
\end{abstract}

\section{ABSTRACT:}

In recent years, the "crisis historiography" became a prominent topic of historiographical discussions. Precipitated or by "reflux" of materialism and structuralism, or by the "return of Literature," at the heart of this crisis we can found new concepts of reality and culture which, inspired by the post-structuralism, by the philosophical "linguistic turn" and by developing a closer relationship with philosophy, literature and psychology, have put in question some of most important paradigms of Social History. This work thus seeks to identify some of these issues to think how the critique to the contextualism and the defense of the subjective interpretation may trigger a review not only about methodological problems but ontological ones of History. Also, considering this critical revision, this paper will explores theoretical possibilities of the approximation of history and literature. However, as says David Harlan, no more to promote a return of ancient writers to the their historical contexts, but to make that some "valuable works of the past" may survive his time so tell us about our present.

Keywords: Historiography; Intellectual history; "Linguistic turn"; Cultural history; Literature; Hermeneutic.

Roger Chartier, David Harlan, Lawrence Stone, Linda Orr, Dominick LaCapra, Lynn Hunt e outros tantos ilustres pensadores da História, escreveram, ao longo das décadas de 80 e 90, importantes análises sobre aquele momento da historiografia ocidental. Cada um à sua maneira compartilhava a constatação: a historiografia enfrentava uma turbulência inédita, que abalava certezas balizares da disciplina. A assim chamada "crise da História" logo se tornou uma temática da historiografia recente, evocada para a proposição de novos horizontes ao campo histórico e/ou na reafirmação da historicidade.

Chartier, por exemplo, mesmo negando a existência de uma crise,$^{1}$ recorre à fórmula para introduzir sua contribuição para uma Nova História Cultural. Semelhante é o caminho de David Harlan (que, diferentemente de Chartier, reafirma a crise), no qual a Nova História Intelectual deva

\footnotetext{
* Historiador, mestrando do Programa de Pós-Graduação em Psicologia Social (UERJ), bolsista Faperj. 1 CHARTIER, Roger. História Hoje: dúvidas, desafios propostas. Revista Estudos Históricos, Rio de Janeiro, vol. 7, n. 13, 1994. Neste artigo, Chartier rejeita a ideia de "crise", já que afirmá-la seria um paradoxo fronte ao crescimento da História no mercado editorial, preferindo, assim, falar em "uma grande mutação": "Assim abalada em suas certezas mais bem-ancoradas, a história se defrontou com vários desafios”. (pp. 1-5).
} 
surgir das próprias críticas e questões que abalam a estabilidade da disciplina histórica. E é seguindo esta orientação, de que momentos de crise são valiosos para a auto-reflexão e para a construção de novos caminhos, que buscaremos compreender a crise da historiografia, sobretudo para explorar perspectivas que se abrem, com destaque na relação entre História e Literatura, com críticas, crises e turbulências.

\title{
1. História, Crise e Mal-Estar
}

O iluminismo está morto, o modernismo está morto, o marxismo está morto, o movimento da classe trabalhadora está morto, e o autor também não se sente muito bem.

Neil Smith

Berger e Luckmann, refletindo sobre a "crise da modernidade", questionam se se trata realmente de uma nova forma de desorientação na vida das pessoas:

\begin{abstract}
Não poderia ser que estivéssemos ouvindo a última repetição de um velho lamento? Não seria a queixa que expressa a angústia que sempre afligiu a humanidade diante de um mundo tornado instável? Seria a velha queixa de que a vida humana é uma vida para a morte? Seria a voz da dúvida de que esta vida poderia encontrar seu sentido numa história transcendente da salvação? Ou este desespero nasce da falta desse sentido?2
\end{abstract}

Embora seja a intenção tratar de outra crise - outra, ao menos, em sentido stricto, ou à primeira vista -, a questão proposta pelos sociólogos se mostra pertinente se atentarmos ao fato de que a crise epistemológica pela qual passa a historiografia nas últimas décadas é vizinha de outras crises, com as quais partilha algumas semelhanças: crise do capitalismo, das ciências sociais, da teoria literária, da arte, da razão, da metafísica, e, claro, aquela que talvez compreenda todas essas citadas, a crise da modernidade.

Partindo dessa suspeita, de que a crise da História é parte de uma mudança cultural mais abrangente que a atravessa e ultrapassa, seguimos com o pressuposto de que "as crises históricas que determinam mudanças históricas acontecem quando muda radicalmente a estrutura da vida". 3 Embora um tanto vaga, a sentença nos remete à parte da questão, "a angústia de um mundo tornado instável". Uma crise, ou é indício, ou sintoma - quando não ambas - de um cenário de instabilidade, e, consequentemente, de angústias, de perda de referências. No que concerne à historiografia, o editorial, de março-abril de 89 da Revista Annales, analisa: "os paradigmas dominantes, que se ia buscar nos marxismos e nos estruturalismos, assim como no uso confiante da quantificação, perdem sua capacidade estruturadora". ${ }^{4}$

2 BERGER, Peter; LUCKMANN, Thomas. Modernidade, Pluralismo e Crise de Sentido: a orientação do homem moderno. Petrópolis: Ed. Vozes, 2005, p. 13.

3 CALDERA, Alejandro Serrano. Filosofia e Crise: Pela filosofia latino-americana. Petrópolis: Ed. Vozes, 1984, p. 14. 4 Histoire et sciences sociales. Un tournant critique?, Annales ESC, 1988, pp. 291-293. Apud CHARTIER, Roger. História Hoje: dúvidas, desafios propostas. Revista Estudos Históricos, Rio de Janeiro, vol. 7, n. 13, 1994, p. 97-113. 
Ou seja, os paradigmas explicativos da realidade, que foram predominantes não somente na historiografia, mas no pensamento social ocidental, até os anos 70 e 80 , foram abalados por novas demandas, inquietações e, sobretudo, como diz o editoral da Annales, pela "transformação da paisagem científica", que levou as disciplinas a um "tempo de incertezas". Pensando na crise das ciências sociais, e na "reconfiguração de pensamento social", diz Geertz:

O que estamos observando não é apenas uma versão mais recente do mapa cultural - a modificação de umas poucas fronteiras mais disputadas, a demarcação de mais alguns pitorescos lagos de montanha - e, sim, uma mudança no próprio sistema de mapear. Algo está sucedendo com a maneira como achamos que pensamos. ${ }^{5}$

Apresentando a crise da história como parte "da crise geral das ciências sociais", o editorial da Annales é citado por Chartier por ser entendido como um "diagnóstico" que denota a "grande mutação que representa o desaparecimento dos modelos de compreensão, dos princípios de inteligibilidade que foram de modo geral aceitos pelos historiadores a partir dos anos $60 .{ }^{6}$ Os métodos quantitativos, estruturais e materialistas, formuladores de leis gerais de explicação do funcionamento da sociedade (p. 98), que "prometem certezas onde estas não podem existir", ${ }^{7}$ permitiram a historiadores e cientistas sociais reforçar suas "ilusões de físicos sociais" (p. 39). Seu desaparecimento, refluxo, ou desgaste, abala não só a certeza sobre o método, mas, e principalmente, a certeza sobre a possibilidade de mensuração das dinâmicas sociais e das questões subjetivas dos "atores sociais". Assim, a descrença quanto à formulações teóricas e metodológicas que traduzem (ou reduzem) o comportamento humano e da sociedade em leis gerais de funcionamento gera, consequentemente, a incerteza quanto a um modus operandi do homem e do mundo social tanto no passado, quanto no presente, e mesmo no futuro. $E$, então, a pergunta: esta angústia não poderia fazer aparecer, ou ecoar, "a voz da dúvida de que esta vida poderia encontrar seu sentido numa história transcendente da salvação?"

Pensando no refluxo do marxismo, tão vigoroso, se não hegemônico, até as décadas de 70 e 80, a pergunta é irônica, mas sugestiva. Já nestas duas décadas, ao menos na Europa continental, o marxismo centrado na análise econômica e nos modos de produção experimentou um "desvio" espetacular do seu programa original. Ou se deveria falar em "desvios". De acordo com Lynn Hunt, para a Cultura e para a Linguagem:

Na história de inspiração marxista, o desvio para a cultura já estava presente na obra de [E. P.] Thompson sobre a classe operária inglesa. Thompson rejeitou explicitamente a metáfora de base/superestrutura e dedicou-se ao estudo daquilo que chamava

5 GEERTZ, Clifford. O Saber Local: novos ensaios em antropologia interpretativa. Petrópolis: Ed. Vozes, 2009, pp. 3435.

6 CHARTIER, Roger. História Hoje: dúvidas, desafios propostas. Revista Estudos Históricos, Rio de Janeiro, vol. 7, n. 13, 1994, p. 97.

7 GEERTZ, C. O Saber Local. . Petrópolis: Ed. Vozes, 2009, p. 35. 
"mediações culturais e morais". 8

Hunt continua, mais à frente, afirmando que "o mais surpreendente exemplo do desvio dos historiadores marxistas para a cultura é o seu crescente interesse pela linguagem". Ela cita Gareth Stedman Jones:

"Não podemos decodificar a linguagem política para chegar a uma expressão primordial e material do interesse, uma vez que é a estrutura discursiva da linguagem política que, em primeiro lugar, concebe e define o interesse." Pode-se considerar ainda marxista um desvio tão radical do programa marxista?" (p. 8). ${ }^{9}$

E a quê se deveria esta guinada à cultura e à linguagem, que tornam ou obsoletos ou deveras desgastados os modelos economicistas e quantitativos? Para Geertz, trata-se de uma mudança cultural. Corrobora neste raciocínio Sandra Pesavento:

Os modelos correntes de análise não davam mais conta, diante da diversidade social, das novas modalidades de fazer política, das renovadas surpresas e estratégias da economia mundial e, sobretudo, da aparentemente escapada de determinadas instâncias da realidade - como a cultura, ou os meios de comunicação de massa - aos marcos racionais e de logicidade. ${ }^{10}$

Neste sentido, a crise da história - e das ciências sociais - é parte de um conjunto de mudanças e transformações que, mesmo ulteriores às ocorridas no pensamento social, o atravessam. É nesta linha que Keith Jenkins propõe repensar a história11 na "pós-modernidade", defendendo a tese de que as mudanças ocorridas na historiografia são reflexos do capitalismo mundial. Embora discordemos do pensamento exemplificado em Jenkins, de que o "contexto", sobretudo econômico, determina inquietações e problemáticas, como se não fosse o "contexto" ele mesmo somente possível de ser formado por problemáticas e inquietações, podemos seguir para a pergunta de Berger e Luckmann que falta: não seria a crise "uma nova versão para a velha queixa de que a vida humana é uma vida para a morte?"

Mesmo que pareça um disparate, a interrogação talvez não seja de todo absurda se observarmos que pensadores "pioneiros", chamados por Jenkins de "pós-modernos", como Michel Foucault, Paul Veyne e Hyden White, vão ter em Nietzsche, a partir de quem se pode pensar Verdade como criação, resposta à necessidade humana de justificar a existência, um importantíssimo interlocutor.

White introduz a sua Meta-História, obra que causou e causa grande desconforto a historiadores que entendem sua disciplina e trabalho como "busca da verdade", criticando a pouca preocupação que historiadores dão à reflexão filosófica, questionando o estatuto da "consciência

8 HUNT, Lynn. Apresentação. In:___org.). A Nova História Cultural. São Paulo: Martins Fontes, 2001, p. 6.

9 Citação: JONES, G. S. Language of Class Studies in English Working Class History, 1832-1982. Cambridge, 1983, p. 22.

10 PESAVENTO, Sandra. História e História Cultural. Belo Horizonte: Ed. Autêntica, 2008, p. 9.

11 JENKINS, Keith. A História Repensada. São Paulo: Ed. Contexto, 2007. 
histórica moderna", e ironicamente alegando que a história não é nem ciência nem arte. Diz ele:

Pensadores da Europa continental - de Valéry e Heidegger a Sartre, Lévi-Strauss e Michel Foucault - expressaram sérias dúvidas sobre o valor de uma consciência especificamente "histórica", sublinharam o caráter fictício das reconstruções históricas e contestaram as pretensões da história a um lugar entre as ciências. Ao mesmo tempo, filósofos anglo-americanos produziram uma alentada bibliografia sobre a posição epistemológica e a função cultural da reflexão histórica, bibliografia que, tomada em conjunto, justifica intensas dúvidas acerca do estatuto da história como ciência rigorosa ou arte genuína. Essas duas linhas de investigação tiveram o efeito de criar a impressão de que a consciência histórica de que se orgulha o homem ocidental desde o início do século XIX talvez não passe de uma base teórica para a posição ideológica a partir da qual a civilização ocidental encara seu relacionamento não só com as culturas e civilizações que a precederam mas também com as que the são contemporâneas no tempo e contíguas no espaço. ${ }^{12}$

A crítica de White sobre a negligência da história - não somente no século XIX, é preciso dizer - para com a epistemologia e, sobretudo, a questão da linguagem é presente não só em MetaHistória. ${ }^{13}$ Em ensaio atribuído à importância da contribuição de Foucault ao pensamento histórico, ele ataca:

O que a moderna teoria linguística demonstra é que as palavras não passam de coisas entre outras coisas no mundo, que elas sempre haverão de obscurecer tanto quanto aclarar objetos que pretendem significar, e que, portanto, todo sistema de pensamento elaborado com a esperança de idear um sistema de representação de valor neutro está fadado à dissolução quando a área das coisas que ele remete à obscuridade emerge para insistir em seu próprio reconhecimento. (p. 255).

As presenças de Foucault e de Nietzsche - pioneiro, por assim dizer, na reflexão sobre a linguagem - aliadas à tradição filosófica analítica fazem do pensamento de White uma posição inovadora, cética e irônica, bastante distinta da tradição historiográfica continental. 0 mal-estar provocado pela sua obra (e, sobretudo pela circulação que ela vem tendo nestes 30 anos) se deve primordialmente à negação de que a História seja uma ciência e que, assim, possa alcançar a verdade, mas que se trata ela de texto, de discurso, de narrativa. Neste sentido, ele a define como "uma estrutura verbal na forma de um discurso narrativo em prosa que pretende ser um modelo, ou ícone, de estruturas e processos passados no interesse de explicar o que eram representandoOS". 14

A recepção de White nas áreas onde o materialismo histórico e a Annales predominavam (ou predominam) é controversa. Os historiadores que se situam na tradição francesa da históriaproblema e da Nova História lidam mais facilmente com a "virada cultural", que, em linha gerais,

12 WHITE, H. Meta-História: a imaginação histórica no século XIX. São Paulo: Edusp, 1992, p. 17-18.

13 "Não pode haver história propriamente dita sem o pressuposto de uma meta-história [uma 'filosofia especulativa da história'] plenamente desenvolvida, pela qual se possa justificar aquelas estratégias interpretativas necessárias para a representação de um dado segmento do processo histórico"; "As distinções convencionais entre historiografia e filosofia da história mais obscurecem do que esclarecem a verdadeira natureza da representação histórica". WHITE, Hayden. Trópicos do Discurso: Ensaios sobre a crítica da cultura. São Paulo: Edusp, 2001, pp. 67-118.

14 WHITE, H. Meta-História. São Paulo: Edusp, 1992, p. 18. (Grifo do autor). 
transformou a noção de cultura - de uma dimensão da experiência histórica para, como diz Hunt (p. 9), o "determinante básico da realidade". ${ }^{15}$ Esta tradição aceita a alegação, sobretudo através de Paul Ricoeur, de que a construção das narrativas históricas procedem de modo semelhante à das ficcionais, mas nega maiores comparações entre elas afirmando que, ao contrário da fiç̧ão, a história lida com realidades passadas e não com a imaginação, por mais que admita que se 0 historiador "visa colocar no seu discurso a realidade de uma sociedade passada, ele reconhece, nesta reconstituição, a ordem e o efeito do seu próprio trabalho". 16

$\mathrm{Na}$ tradição marxista ligada ao economicismo, "viradas" cultural e linguística circulam com menos desenvoltura, por assim dizer. Em artigo destinado a discutir a história "pós-moderna" e "póslinguistic turn", o historiador do trabalho Dick Geary nos brinda com uma interessante afirmação, que mais parece um ultimato:

O historiador que negar que não exista nada "lá fora" além de nossas construções culturais, deve abandonar a profissão. Afinal, a história não é ficção e devemos estar cientes das regras de evidência, que necessariamente excluem alguns tipos de interpretação, mesmo que não nos garantam nenhuma segurança. ${ }^{17}$

A frase de Geary pode nos sugerir que, para-além de uma crise de paradigmas, passa a história por uma crise existencial - claro que tomando a expressão como figura de linguagem - cujo eixo é a capacidade da história de espelhar a verdade e o real. As "regras de evidência" levariam 0 historiador a poder distinguir o verdadeiro do imaginado, o mito da realidade, o que de fato existe "lá fora" (no passado?) das construções subjetivas. Mas as provocações pós-estruturalistas não vêm, neste ponto, discutir as "regas de evidência", ou, como diz Ginzburg, o método que comprova a veracidade das fontes, mas a própria noção de que existe uma verdade a ser comprovada e uma realidade passível de ser desvelada em sua íntegra, por mais que estas tenham ganhado nos últimos anos a alforria do fardo de serem tratadas no singular. Em suma, a capacidade da história de dizer o que realmente aconteceu, mesmo que o discurso historiográfico, desde a primeira Annales, tenha se esforçado em se autoafirmar antipositivista.

A fenda que se abre com a contribuição dos ditos "pós-modernos" talvez seja não a crise propriamente dita, como um período de instabilidade, mas a possibilidade de pensá-la, a própria crise, como uma figura retórica que representa o fim da ilusão da verdade. Com White, o "retorno da literatura"18 e a redescoberta de Nietzsche como filósofo da história, se pode hoje conjeturar que,

15 Em Pesavento: "Trata-se de pensar a cultura como um conjunto de significados partilhados e construídos pelos homens para explicar o mundo". PESAVENTO, S. História e História Cultural. Belo Horizonte: Ed. Autêntica, 2008, p. 15. 16 CERTEAU, Michel de. A Escrita da História. Rio de Janeiro: Forense Universitária, 1982, p. 46.

17 GEARY, Dick. A "Virada Linguística", Pós-Modernismo e História do Trabalho. Revista Perspectiva. Florianópolis, v.18, n.33, pp. 35-63, jan./jun. 2000. (Grifo do autor). Disponível em: http://www.periodicos.ufsc.br/index.php/perspectiva/article/view/9384/8634

18 Para David Harlan, "o retorno da literatura mergulhou os estudos históricos numa profunda crise epistemológica, questionando nossa crença num passado fixo e determinável, comprometendo a possibilidade de representação 
uma vez que signo linguístico, a verdade talvez não esteja "lá fora", mas na construção discursiva; e, assim, o critério do "verdadeiro" não se refere propriamente aos fatos, mas à disposição destes no jogo de linguagem próprio da disciplina, já que "o fato é apresentado no lugar e no modo como se apresenta no discurso a fim de sancionar a interpretação para a qual ele supostamente contribui". 19 Objetivo último da história, seria "a verdade" criação humana derivada da vontade de dar ordem ao caos e sentido ao absurdo?

Embora o mal-estar causado por Hayden White seja presente, sua crítica vem sendo combatida, seja com veemência por desafetos ${ }^{20}$, seja por historiadores que mergulharam no fluxo aberto por suas ousadas contribuições. Por partir do pressuposto de que história é discurso textual, White adotou em Meta-História uma metodologia formalista, que, limitando-se aos aspectos formais do texto, teria reduzido a complexidade do pensamento histórico a poucos tropos discursivos.

Outra crítica dirigida à Meta-História alega que White rompe com as barreiras entre história e ficção, de modo que teria "convertido a história em uma modalidade de ficção". ${ }^{21}$ Embora a primeira crítica seja deveras relevante - mesmo que, em Meta-História, White use os tropos para se referir especificamente ao pensamento histórico do século XIX - a segunda nos parece injusta, ou pelo menos reducionista. Não se trata de pensar a história como ficção, mas, antes, de afirmar que ela é discurso, e, assim sendo, é atravessada por elementos retóricos dispostos ao historiador na sua investida aos fatos passados.

Um discurso histórico não deve ser considerado uma imagem especular do conjunto de eventos que ele afirma simplesmente descrever. Ao contrário, deve-se ver no discurso histórico um sistema de signos que aponta em duas direções ao mesmo tempo: primeiro, para um conjunto de eventos que tenciona escrever e, segundo, para a forma genérica de estória à qual ele tacitamente equipara o conjunto a fim de expor a sua coerência formal, considerada ou como estrutura ou como processo. ${ }^{22}$

Dedicando-se a pensar as relações entre história e literatura, Luiz Costa Lima diferencia 0 discurso histórico do ficcional por este "não postular uma verdade", mas sim pô-la "entre parênteses" (p. 21), e externa o que pode ser entendido como um dilema da historiografia nos últimos anos:

A historiografia tem um trajeto peculiar: desde Heródoto e, sobretudo, Tucídides, a escrita da história tem por aporia a verdade do que houve. Se se lhe retira essa prerrogativa, ela perde sua função. Torna-se por isso particularmente difícil ao historiador não considerar prova aporética o que resulta do uso de suas ferramentas operacionais.

histórica e abalando nossa habilidade de nos localizarmos no tempo". HALAN, David. A História Intelectual e o Retorno da Literatura. In: RAGO, M.; GIMENES, R. Narrar o Passado, Repensar a História. Campinas: Ed. Unicamp, 2000, p. 16.

19 WHITE, H. Trópicos do Discurso. São Paulo: Edusp, 2001, p. 124.

20 Ver GINZBURG, Carlo. O Fio e os Rastros. Verdadeiro, falso, fictício. São Paulo: Cia. das Letras, 2007. O historiador italiano apresenta este livro como uma resposta aos "inimigos" céticos e pós-modernos: "não era possível combater 0 neo-ceticismo repetindo velhas certezas. Era preciso aprender com o inimigo para combatê-lo de modo mais eficaz".

21 LIMA, Luiz Costa. História. Fiç̧ão. Literatura. São Paulo: Cia. das Letras, 2006, p. 21.

22 WHITE, H. Trópicos do Discurso. São Paulo: Edusp, 2001, p. 123. 
(Idem).

Para Costa Lima, reconhecer que a história é sustentada pela aporia da verdade não deve significar que historiadores reduzam-na ao "exame das marcas verbais", pois "o discurso compreende muito mais do que isso". (p. 27). Contudo, querer e não querer representar a verdade, como distinção entre literatura não-ficcional e ficcional, talvez não seja o suficiente para encerrar um debate que, como mostra o próprio Lima, não é recente, mas remonta ao mundo antigo. Vê-se a distinção entre tragédia e história ensaiada por Políbio (205/200-120 a. C.): "na arte do primeiro é a verossimilhança que mais importa, mesmo se o fundo é falso, isso porque se trata de seduzir os espectadores. Na arte do segundo, é a verdade que comanda, pois se trata de ser útil aos espíritos estudiosos". ${ }^{23}$ E agora a comparemos com a defesa de Edgar de Decca, de que a diferença entre história e fiç̧ão

está no fato de que a narrativa historiográfica moderna sustenta-se a partir de elementos pré-textuais, empíricos, que são os documentos, submetendo-se, assim, aos critérios da prova, uma exigência própria do campo das ciências sociais. ${ }^{24}$

A afirmação de Decca representa aqui a posição dos historiadores que entendem a história como ciência; o curioso, contudo, é que mesmo 80 anos depois da aurora dos Annales, este discurso precise se embasar na pressuposição de que os documentos são capazes de "provar cientificamente" as verdades históricas. Questionando esta posição, Antonio Paulo Benatte argui: "será mesmo que os documentos são 'elementos pré-textuais, empíricos'?", e responde explicando:

\begin{abstract}
A teoria do conhecimento designa como empiria uma experiência sensível bruta, antes de toda e qualquer elaboração racional. Ora, mesmo os pré-conceitos com que os historiadores se dirigem às fontes já constituem uma intervenção racional necessária do sujeito cognoscente. Além disso, e justamente ao contrário de qualquer pré-textualidade, todo corpus documental que o historiador organiza e utiliza na pesquisa dita empírica (e não apenas os documentos escritos em linguagem verbal) constituem, como diz Linda Hutcheon, vestígios textualizados do passado. O historicismo pós-moderno presente naquele gênero literário a que a autora chama de "metaficção historiográfica", e que embaralha deliberada e criticamente os códigos convencionais da historiografia e do discurso ficcional, não nega que o passado tenha realmente existido antes de sua textualização na ficção ou na história. Mas ele também demonstra "que ambos os gêneros constroem inevitavelmente à medida que textualizam esse passado. 0 referente 'real' de sua linguagem já existe, mas hoje só nos é acessível em forma textualizada: documentos, relatos de testemunhas oculares, arquivos. O passado é 'arqueologizado', mas sempre se reconhece seu repositório de materiais disponíveis como sendo textualizado". Nesse sentido, a matéria bruta do discurso histórico não é o documento, mas, como em todo discurso, a linguagem. ${ }^{25}$
\end{abstract}

Para White, além de história e ficção se encontrarem, como expressado acima, na

23 PÓLIBIO. Histoire. Paris: Gallimard, 2003, II, III, 11-2. Apud: LIMA, L. C. op. cit., pp. 171-172.

24 DECCA, E. S. Narrativa e História. In: SAVIANI, D.; LOMBARDI, J. C.; SANFELICE, J. L. (orgs.) História e História da Educação. Campinas, 1998, p. 21. Apud: BENATTI, Antonio Paulo. História, Ciência, Escritura e Política. In: RAGO, M.; GIMENES, R. Narrar o Passado, Repensar a História. Campinas: Ed. Unicamp, 2000. (Grifos Meus).

25 BENATTE, A. P. op. cit., p. 91. (Grifos do autor). Citação: HUTCHEON, L. Poética do Pós-Modernismo: história, teoria, ficção. Rio de Janeiro: Imago, 1991, p. 172. 
textualidade, elas se encontram também nos discursos tanto daqueles que "querem dizer a verdade" quanto daqueles que "não o querem": "ambos discursos querem oferecer uma imagem verbal da 'realidade'". ${ }^{26}$ Decerto, tanto encerrar a literatura ficcional na breve e equivocada definição de entretenimento, ou de discurso que não quer dizer a verdade, quanto afirmar, por outro lado, que ela quer oferecer uma imagem verbal da realidade, é praticar um reducionismo imperdoável frente aos vários e diversos tipos, tropos, estilos, gêneros e, ouso dizer, autores que a constituem.

Contudo, pensando no caráter mimético da ficção, não se pode negar que ela é construída por elementos verbais que se referem ao que a tradição racionalista da história chama de "realidade". Diz White: "a imagem da realidade assim construída pelo romancista pretende corresponder, em seu esquema geral, a algum domínio da experiência humana que não é menos 'real' do que o referido pelo historiador". Se quer dizer com isso que, se por um lado o discurso histórico é construído, enquanto texto, a partir dos mesmos artefatos verbais que o ficcional, este, por outro lado, "deve passar por um teste de correspondência (deve ser 'adequada' como uma imagem de alguma coisa que está além de si mesma) se pretender apresentar uma visão ou iluminação da experiência humana do mundo". Neste sentido, "todo discurso escrito se mostra cognitivo em seus fins e mimético em seus meios".

É deveras relevante a alegação de que a intenção do escritor de ficção é diferente da intenção do historiador, bem como a afirmação que o último, diferentemente do primeiro, "necessita centralmente de um aparato documental". ${ }^{27}$ Contudo, é arenoso manter a distinção entre os dois sem reconhecer que a ficção também pode ser construída a partir de aparatos documentais, procedendo - inclusive metodologicamente - de modo semelhante ao do fazer História, bem como sustentar a veracidade da narrativa histórica a partir da evocação de poderosas palavras como "fato" e "fonte".

Fonte histórica, por definição, é tudo aquilo que possa levar o historiador ao passado. Não todo e qualquer passado, mas àquele que ele julgar relevante para a explicação de um evento ou de uma estrutura: ou seja, àquilo que ele determinar como fato histórico. Assim, a fonte está para 0 fato, como o fato está para a fonte, e a existência de ambos depende fundamentalmente do julgamento do historiador: depende da sua interpretação. A tradição positivista, empenhada em fazer da história uma ciência rigorosa, à luz da cientificidade e do racionalismo, fez com que 0 pressuposto de que "os fatos falam por si só" ganhasse imensa força - inclusive argumentativa, retórica - nos domínios historiográficos.

Para os positivistas, os fatos estavam "lá" ("lá fora"?), e caberia ao historiador lhes dar voz, 
sem que neles intervisse. Coube a Marc Bloch, Lucien Febvre e à primeira Annales a primeira crítica capital a este pressuposto, alegando que o historiador deve problematizar as fontes, de modo que se passasse a fazer uma história-problema, e não mais uma história factual.

Se as fontes devem ser problematizas, contextualizadas, ou seja, se deve, antes de dar-lhe voz, conhecer qual o contexto histórico que as produziu. A historiografia pós-Annales - sobretudo a partir de Fernand Braudel - se voltou para o estudo das "estruturas" e não mais dos "fatos" per se. A historiografia predominante, então, tanto na Europa continental quanto na América Latina, sobretudo a partir do pós-45, rejeitou os chamados "grandes acontecimentos", os eventos, os "grandes personagens", alegando que estes não seriam capazes de mostrar as mudanças e as realidades históricas, voltando, assim, sua atenção para as "tendências gerais", a longa duração, as estruturas que permitem existir os eventos. Mesmo o marxismo, principal "rival" da Annales até a dita crise, rejeita a história dos acontecimentos, porque esta

não apenas expressa o ponto de vista das classes dominantes sobre o devir histórico da humanidade, como não é suficientemente racional para analisar as 'leis' científicas explicativas dos processos dialéticos da história, bem como a complexidade da luta de classes que era seu motor de combustão. ${ }^{28}$

Assim, tanto o marxismo quanto a História-problema rejeitaram os eventos, mas mantiveram do positivismo o pressuposto da História ciência, seja através da história contextual, seja através da dialética materialista. E para ser a História uma ciência rigorosa, não pode ela estar à mercê da interpretação do historiador, mesmo que os historiadores concordem, desde Marc Bloch, que são filhos do seu tempo. Contudo, ser filho do tempo significa pertencer a um contexto, a uma estrutura, e negar que a construção de um fato histórico seja obra da interpretação do historiador é parte da legitimação da História enquanto ciência: capaz de descrever "o que realmente aconteceu". Diz Benatte:

\footnotetext{
A abordagem voltada para longos períodos e informada por modelos teóricos rigorosos de uma história cada vez mais quantitativa, serial e largamente matematizada, pressupunha a recusa de uma historiografia meramente descritiva e literária. (...) Os historiadores ligados aos Annales foram marcados por um ideal de ciência histórica "desembaraçada da determinação das palavras e das frases da história, capaz assim de transformar em conhecimentos reais 0 que não era ainda senão o 'romance da vida humana"'. ${ }^{29}$
}

A distinção, assim, entre Literatura e História se dá sobre bases supostamente cientificistas, que separam, de um lado, o fato, a conjuntura, o contexto, o documento, a verdade e o que realmente aconteceu do lado da ciência, e o mito, a invenção, a falsidade, a opinião e a interpretação do lado da ficção. De acordo com White, esta tradição...

28 BENATTE, Antonio Paulo. História, Ciência, Escritura e Política. In: RAGO, M.; GIMENES, R. Narrar o Passado, Repensar a História. Campinas: Ed. Unicamp, 2000, p. 79.

29 Citação: RANCIĖRE, Jacques. Os Nomes da História: um ensaio de poética do saber. São Paulo: EDUC/Pontes, 1994, p. 13. 
trabalhando com a convicção de que as intuições poéticas e científicas são mais diferentes do que semelhantes, têm-se preocupado em recuperar a reivindicação de um status científico por parte da história - e, portanto, tendem a diminuir a importância do elemento interpretativo nas narrativas históricas. Inclinaram-se a inquirir até que ponto uma narrativa histórica pode ser considerada algo de diferente de uma simples interpretação, na suposição de que o que é interpretação não é conhecimento mas apenas opinião, e na crença de que o que não é objetivo num sentido científico não é digno de ser conhecido. ${ }^{30}$

A separação entre fato - seja evento ou estrutura - e interpretação sustenta, assim, ainda hoje, a pretendida cientificidade do conhecimento histórico, a afirmação da racionalidade científica da disciplina. Entretanto, fato e interpretação não só não se excluem, como são interdependentes. Mais uma vez com White:

O fato é apresentado no lugar e no modo como se apresenta no discurso a fim de sancionar a interpretação para a qual ele supostamente contribui. E a interpretação deriva sua plausibilidade da ordem e maneira como os fatos são apresentados no discurso. O próprio discurso é a verdadeira combinação dos fatos e dos sentidos que Ihes confere 0 aspecto de uma estrutura específica de sentido que nos permite identificálo como produto de um tipo de consciência histórica e não de outro. (p. 124).

\section{2. "Mas somos nós os coloristas"}

A coisa em si é digna de uma homérica gargalhada: ela parecia tanto, e mesmo tudo, e, propriamente, é vazia, ou seja, vazia de significação.

Nietzsche

Mesmo que negada, é a interpretação do historiador responsável por "criar" os fatos históricos. Mesmo que lide com a realidade, a História se manifesta discursivamente, em textos mesmo que não escritos -, portanto não escapa à retórica e aos jogos de linguagem. E mesmo que os discursos não se limitem aos aspectos formais dos textos, como nos adverte Costa Lima, a linguagem que os atravessa não se restringe ao exercício de comunicar aos outros; mas, antes, elemento cultural, é parte fundamental da construção da subjetividade.

A afirmação de que a realidade que o historiador tenciona desvelar não está estritamente "lá fora", mas na construção discursiva e na sua interpretação, não traz, em absoluto, demérito algum à profissão, tampouco diminui a importância do seu trabalho para o conhecimento da história. Muito pelo contrário. Uma vez que a linguagem que o constitui e a seu texto é elemento cultural, e, portanto, constructo social e histórico, sua interpretação, seu trabalho, é real, ou seja, é constituinte da realidade. A crítica aqui se situa, portanto, não na rejeição à História, nem ao fazer História, mas ao frutífero racionalismo que, há muito, separa Verdade de aparência, e que, na História, faz pressupor que há sentidos e significados numa realidade que, livre e independente das construções históricas, subjetivas e interpretativas, se faz alcançável através de métodos rigorosos e objetivistas.

30 WHITE, H. Trópicos do Discurso. São Paulo: Edusp, 2001, p. 69. (Grifo do autor). 
Como sustenta Gadamer:

O conhecimento histórico não pode ser descrito segundo o modelo de um conhecimento objetivista, já que ele mesmo é um processo que possui todas as características de um acontecimento histórico. A compreensão deve ser entendida como um ato da existência, e é portanto um "pro-jeto lançado". O objetivismo é uma ilusão. Mesmo como historiadores, quer dizer, como representantes de uma ciência moderna e metódica, somos membros de uma cadeia ininterrupta graças a qual o passado nos interpela. ${ }^{31}$

Ora, a crítica "metalinguística" não questiona a existência da realidade, mas argumenta que entre o real - a referência - e suas representações, um hiato se faz presente; e que esse abismo entre coisas e signos faz com que qualquer tentativa de mensuração da realidade seja condenada ao fracasso - e, dizemos, com base em Gadamer: independente do método. E já que não negamos a realidade, o que seria afirmação absurda, faz-se preciso pensar também sobre este pontoreferência das construções discursivas. Em outros termos, reforçar o seu caráter "pendente", já que nem as representações do real nem a própria realidade gozam de uma existência a-histórica: rija, acabada, fática e imutável. Dizendo com as palavras de Ernst Bloch, não é a realidade um conjunto de fatos consumados, mas sim processo, devenir, permanente transformação: "é mediação vastamente ramificada entre o presente, o passado pendente e sobretudo o futuro possível". ${ }^{32}$

Mas continuemos na questão do objetivismo, pois este ponto aqui tem função específica, fundamental para o desenvolvimento do trabalho, que é relacionar dois domínios recentes da historiografia contemporânea, a saber, as "novas" histórias intelectual e cultural. ${ }^{33}$ E 0 faremos dando seguimento a este raciocínio, com uma preciosa contribuição de Nietzsche:

Os filósofos costumam colocar-se diante da vida e da experiência como diante de uma pintura, que está desenrolada de uma vez por todas e como inalterável firmeza mostra 0 mesmo evento: esse evento, pensam eles, é preciso interpretá-lo corretamente, para com isso tirar uma conclusão sobre o ser que produziu a pintura: portanto, sobre a coisa em si, que sempre costuma ser considerada como razão suficiente do mundo do fenômeno. Em contrapartida, lógicos mais rigorosos (...) puseram em questão toda conexão entre o mundo metafísico e o mundo que nos é conhecido: de tal modo que no fenômeno, justamente, a coisa em si não aparece. De ambos os lados, porém, não é levada em conta a possibilidade de que essa pintura - aquilo que agora, para nós homens, se chama vida e experiência - pouco a pouco veio a ser e, aliás, está ainda em pleno vir-a-ser e por isso não deve ser considerada como grandeza firme. (...) É porque nós, desde milênios, temos olhado para o mundo com pretensões morais, estéticas, religiosas, com cega inclinação, paixão ou medo, e porque temos regalado nos maus hábitos do pensamento ilógico, que esse mundo pouco a pouco veio a ser tão maravilhosamente colorido, apavorante, profundo de significação, cheio de alma; ele

31 GADAMER, Hans-George. O Problema da Consciência Histórica. Rio de Janeiro: Ed. FGV, 2003, pp. 57-58. (Grifo do autor).

32 BLOCH, Ernst. O Princípio Esperança. Vol. 1. Rio de Janeiro: EdUERJ, 2006, p. 194.

33 Exploramos perspectiva semelhante ao do já citado trabalho organizado por Lynn Hunt, "A Nova História Cultural". Nele, há em diversos momentos a sugestão de que a "nova" História Intelectual está em íntima relação com a Nova História Cultural, se não é parte dela. Destaque para o capítulo "Literatura, Crítica e Imaginação Histórica: o desafio literário de Hayden White e Dominick LaCapra" (pp. 131-173) de Lloyd S. Kramer: "o tema recorrente da história intelectual é o de que as estruturas de pensamento e significado simbólico são parte integrante de tudo que conhecemos como história". (p. 133). 
adquiriu cores - mas somos nós os coloristas. ${ }^{34}$

"Mas somos nós os coloristas"! A realidade, desprovida de sentidos e de significações, é uma pintura sem cor, quiçá um quadro sem cor e sem formas, nem mesmo abstratas. Essa realidade, coisa-em-si, tão almejada pelo espírito racionalista, que, segundo ele, independe da intervenção subjetiva - e, mais, é alterada se for interpretada - é, como sustenta Nietzsche, vazia: vazia de significação. 0 cientificismo guarda como norte "a verdadeira interpretação" de uma obra, 0 des-velar "do que realmente aconteceu" desafetado de subjetividade, quando são as pretensões morais, estéticas, religiosas, as paixões e os medos, que dão cores ao mundo: à vida e à experiência.

O pressuposto assumido nos abre duas possíveis vias de relacionamento com duas "novas histórias". Uma, Cultural, na intenção de "identificar o modo como em diferentes lugares e momentos uma determinada realidade social é construída, pensada, dada a ler"35, a afirmação de que "as próprias representações do mundo social são os componentes da realidade social" ${ }^{36} \mathrm{~A}$ outra, Intelectual, bem menos estruturada que a primeira, na indicação de que se deve abandonar a busca pela "real intenção do autor" e de que o contextualismo pode tanto clarear quanto obscurecer o discurso histórico.

José Murilo de Carvalho ${ }^{37}$ diz que a História Intelectual ficou durante muito tempo refém de duas únicas fórmulas de trabalho: uma, centrada na produção de um único e específico pensador, pressupondo ser possível interpretar suas ideias com exatidão; outra, indo um pouco mais além, ao articular obras de alguns pensadores, forja "famílias de pensamento" e correntes intelectuais: "nessas histórias, os pensadores eram agrupados e se discutiam seus pontos de coincidência e de desacordo, estabelecendo-se certa intertextualidade". (p. 123).

Se, à primeira, se faz presente a atenção de que a ideia de autor "persegue a ideia de unidade", sugerindo integridade e totalidade, sustentando "a ideia igualmente vigorosa de que deve haver uma interpretação exata e correta" e acaba por evocar uma presença idealizada do "autor" na sua "obra". ${ }^{38}$ Referente à segunda fórmula, faz-se a pergunta:

Esta lista de trabalhos, arranjados nesta linha de ordem cronológica, é ela o produto de

34 NIETZSCHE, Friedrich. Humano, Demasiado Humano, cap. 1, § 16. In: Coleção Os Pensadores. São Paulo: Abril Cultural, 1983, pp. 93-94.

35 CHARTIER, Roger. A História Cultural: entre práticas e representações. Lisboa: Difel; Rio de Janeiro: Bertrand Brasil, 1988, pp. 16-17.

36 CHARTIER, R. Intellectual History or Sociocultural History?: The French Trajectories. In: LaCAPRA, Dominick; KAPLAN, Steven L. (orgs.). Modern European Intellectual History: reappraisals and new perspectives. Ithaca: Cornell University Press, 1982, p. 30.

37 CARVALHO, José Murilo. História Intelectual no Brasil: a retórica como chave de leitura. Revista Topoi, Rio de Janeiro, n.1, pp. 123-152. Disponível em: http://www.ifcs.ufrj.br/ ppghis/pdf/topoi1a3.pdf

38 NEVES, Luiz Felipe Baêta. A Construção do Discurso Científico: implicações sócio-culturais. Rio de Janeiro: Ed. UERJ, 1998, pp. 52-57. 
um genuíno processo histórico? Ela representa verdadeiramente as vozes encorpadas de uma grande conversação que tem se desenvolvido ao longo das eras? Estariam os grandes pensadores de todas as épocas realmente conversando uns com os outros, numa extensa conversa histórica, sendo os grandes livros os remanescentes textualizados desde elevado diálogo ${ }^{39}$

A crítica a este modelo, que Skinner chamou, em 196640, de "modelo de influência" não é, obviamente, tão recente. Face à constatação de que os "grandes diálogos" entre os "grandes pensadores" são construções intelectuais concebidas pelos historiadores contemporâneos, uma História Intelectual foi edificada, sobretudo ao redor das contribuições de Quentin Skinner, John Pocock e John Dunn, na busca por restaurar a historicidade das ideias e das produções intelectuais. E é este o paradigma atual da História Intelectual: a aposta de que a devida contextualização da obra pode dar ao historiador, ao crítico, a real dimensão da obra e do autor, ou seja, que ela pode revelar o que obra e autor "realmente querem dizer".

Frágil, todavia, ao "massacre do pós-estruturalismo", 41 esta História Intelectual põe em jogo pressupostos semelhantes aos já criticados anteriormente, de que uma devida interpretação deve livrar-se do que Adorno chamaria de "aquela espontaneidade subjetiva", em favor da "verdade do texto". Diz Harlan:

A proposta de Skinner e de Pocock para a reforma da história intelectual é necessariamente uma proposta protestante. Tal como Lutero, eles afirmam que os textos históricos transmitem significados fixos, e que estes significados são acessíveis e, em última análise, determináveis, se os críticos ou os historiadores simplesmente se derem ao trabalho de atravessar as camadas de interpretação que se põem entre o texto não corroborado e as mentes inquisidoras. Tal como Lutero, eles consideram estas camadas de interpretação acumulada como se fossem um impedimento, uma obstrução, um obstáculo, uma barreira entre os historiadores e as "intenções primárias" do autor. A riqueza do material interpretativo que cerca um trabalho histórico é por eles tida como uma incrustação numa escala tal que os historiadores precisam esmagá-la em pedaços com seu "método verdadeiramente histórico", de modo a obter a pérola do significado autêntico, aquilo que 0 autor "realmente quis dizer", aquilo que 0 texto "realmente diz". (pp. 46-47).

Contra as pretensões do "realmente quis dizer" e de um contextualismo ortodoxo que, em vez de aclarar o texto, pode acabar por aprisioná-lo numa suposta verdade histórica, David Harlan propõe:

Precisamos é de uma tradição interpretativa construída não sobre o anseio pela presença do autor e pelo significado invariável, não sobre a ilusão do texto como uma "intencionalidade congelada esperando para ser novamente experienciada", mas no reconhecimento de que todo texto, no mesmo momento em que começa a existir, já foi atirado nas águas, que nenhum texto pode jamais esperar novamente juntar-se a seu pai, que é o destino de todo texto dar início ao caminho errante de um filho pródigo que

39 HALAN, David. A História Intelectual e o Retorno da Literatura. In: RAGO, M.; GIMENES, R. Narrar o Passado, Repensar a História. Campinas: Ed. Unicamp, 2000, p. 44.

40 SKINNER, Quentin. The Limits of Historical Explanation. Philosophy, 41, 1966, pp. 199-215.

41 "O massacre do pós-estruturalismo deixou a história intelectual com um cânone, mas sem uma explicação histórica de sua existência. Os historiadores intelectuais exploram minunciosamente uma pilha de ossos, em busca do que uma vez tinha sido o esqueleto". HARLAN, D. op. cit., p. 46. 
não mais retorna. (p. 47).

Ou seja, o texto, como um filho errante, tem "vida própria", e não possui, assim, significados fixos. Enquanto crítica ao contextualismo, essa passagem de Harlan nos remete à metáfora hegeliana dos frutos das musas, citada por Gadamer:

As obras das musas são agora o que são para nós - belos frutos arrancados da árvore; um destino amável no-lo ofereceu, como uma jovem presenteia aqueles frutos; não existe a vida real na existência, não existe a árvore que os produziu, não há a árvore nem os elementos que perfizeram sua existência nem o clima que perfez sua determinação, nem a mudança das estações que dominavam o processo de seu devir. Assim, como as obras daquela arte, o destino não nos dá o mundo, nem a primavera ou 0 verão da vida moral em que floresceram e maduraram, mas apenas a lembrança velada daquela realidade. ${ }^{42}$

Mas, se por um lado a relação entre texto e contexto não é suficiente para garantir validade científica - cientificista - ao método e à interpretação, ${ }^{43}$ pelo menos não ao que 0 contextualismo mesmo se propõe, a verdadeira interpretação da verdade da obra, por outro, o idealismo hegeliano e a negação da História - ou do fazer História como conhecemos hoje - pode ocorrer no que Baêta Neves chamou de "erro máximo": 0 anacronismo. ${ }^{44}$

Faz-se necessário, pois, superar o impasse que se forma na radicalização das fórmulas: a textualização do contexto pode levar ao abandono da História, na medida em que a abordagem ao discurso se limite puramente aos seus aspectos formais, e, assim, por um lado, acabe por "atribuir a autores e obras intenções e significados que sequer poderiam ter imaginado em seus contextos originários de formulação" (p. 344), e, por outro, pressuponha o vazio: ou seja, perca de vista a realidade que serve de referência ao discurso - não somente o histórico, mas a toda construção linguística.

Afirmamos, com Chartier, que "deve-se constatar que toda construção de interesses pelos discursos é ela própria socialmente ${ }^{45}$ determinada, limitada pelos recursos desiguais de que dispõem os que a produzem". 46 Contudo, é preciso cuidar, como diz o chavão popular, para não jogar a criança fora com a bacia d'água. Se a limitação aos aspectos formais dos textos pode

42 HEGEL, G. W. F. Phänomenologie des Geistes. Ed Hoffmeister, p. 524. Apud: GADAMER, H. G. Verdade e Método I. Petrópolis, Ed. Vozes, 1999, p. 267.

43 Até porque, como nos provoca LaCapra, o "contexto" histórico é somente passível de conhecimento através de textos. Portanto, contextos são textos, e não relatos fidedignos "do que realmente aconteceu", e, assim sendo, a eles se colocam todas as questões relativas à retórica e à hermenêutica. Ver LaCAPRA, Dominick. Rethinking Intellectual History: texts, contexts and Language. Ithaca; London: Cornell University Press, 1985; LaCAPRA, D. History and Criticism. Ithaca; London: Cornell University Press, 1985. Em outro local ele resume: "opino que a contextualização é uma condição necessária mas não suficiente para a compreensão histórica, particularmente na história intelectual e cultural, donde também são pertinentes os temas dialógicos e críticos de leitura e resposta". LaCAPRA, D. Historia em Tránsito: experiencia, identidad, teoría crítica. Buenos Aieres: Fondo de Cultura Económica, 2006, p. 105.

44 NEVES, Luiz Felipe Baêta. História Intelectual e História da Educação. Revista Brasileira de Educação, vol. 11, n.32, maio/ago.2006. Disponivel: http://www.scielo.br/pdf/rbedu/v11n32/a12v11n32.pdf

45 Lembrando que, para Chartier, o cultural precede, ou constitui, o social.

46 CHARTIER, Roger. História Hoje: dúvidas, desafios propostas. Revista Estudos Históricos, Rio de Janeiro, vol. 7, n. 13, 1994, p. 102. 
apologizar o vazio, a negação da linguagem em prol do contexto encerraria o tema em mais um dualismo. A textualização do contexto não precisa entender a linguagem como um conjunto estanque de signos. ${ }^{47}$ Um querer historicizar que nega a linguagem porque ela negaria o que é de mais caro à História, o contexto, acaba por des-historicizar a própria linguagem. Como as "normas" e as "convenções", a linguagem é mutante e mutável:

O objeto fundamental de uma história cujo projeto é reconhecer a maneira como os atores sociais investem de sentido suas práticas e seus discursos parece-me residir na tensão entre as capacidades inventivas dos indivíduos ou das comunidades e os constrangimentos, as normas, as convenções que limitam - mais ou menos fortemente, dependendo de sua posição nas relações de dominação - o que lhes é possivel pensar, enunciar e fazer. ${ }^{48}$

É nossa intenção aqui, como sustentado outrora, negar o vazio; reafirmar a história e a historicidade, mas através de uma prática interpretativa que se assuma interpretação, sem que com isso ocorra de ser tachada "pura opinião", com se opiniões se pudessem puras, como se as cores independessem por completo de quem as pinta. Um fazer História em que "as camadas de interpretação acumulada" em vez de serem vistas como impedimento, representem, ao contrário, parte fundamental, vital, do trabalho, como sugere Gadamer. ${ }^{49}$

Aprofundando o duplo caráter dos textos ${ }^{50}$, mas rompendo com o dualismo, Gadamer nos orienta para a compreensão de que estas, no dizer de Harlan, "camadas de interpretação acumulada", fornecidas pela "tradição", formam o "arco hermenêutico" através do qual quem interpreta se relaciona com a obra interpretada. Deste modo, as contribuições (e nossa relação com elas) feitas por outras interpretações não atrapalham, muito menos impedem a compreensão do texto. Por mais que as "famílias pensamento", a estruturação e organização de obras e autores em estilos, gêneros, escolas intelectuais e tradições, sejam criações de historiadores e críticos, e que

47 Para o antropólogo Marshall Sahlins, a compreensão da linguagem como uma "prisão" - "e esse é de fato o atual 'discurso hegemônico'" - seria uma nova versão de um antigo dualismo que, na cultura hebraico-cristã separou homem e natureza, e, na modernidade, rivalizou indivíduo e cultura. De acordo com Sahlins, em vez de protagonizar um novo dualismo, a linguagem poderia ser um caminho para ultrapassá-los, uma vez que "os signos se transformam na ação [na prática, na criação] individual”. Ver SAHLINS, Marshall. Cultura na Prática. Rio de Janeiro: Ed. UFRJ, 2004, especialmente o capítulo 16 "A Tristeza da Doçura, ou a Antropologia Nativa da Cosmologia Ocidental", pp. 563-619.

48 CHARTIER, R. 1994, p. 102.

49 Na sua crítica à hermenêutica tradicional, Gadamer, além de sustentar que um texto nunca se esgota na "intenção do autor", porque, com o passar do tempo, ele vai ganhando e perdendo significados e sentidos, nos abre duas mais preciosas frestas à interpretação: 1) a tradição, ou seja, as interpretações que são (foram) feitas a uma obra no passar dos tempos, formam um "arco (ou "círculo") hermenêutico" através do qual o "mundo" de quem interpreta dialoga com a obra interpretada; 2) nossos preconceitos (ou juízos prévios, ou pré-compreensões), formados também por este "arco", constituem a própria hermenêutica: nossos preconceitos não são, pois, impedimentos à compreensão, mas, pelo contrário, são eles que nos possibilitam conhecer. No nosso caso, são os preconceitos que vão, sobretudo, lançar luz sobre o que, no passado, nos inquieta hoje: na afirmação de que os aspectos aclarados nos textos assim se evidenciam, bem como as intertextualidades, não por estarem "lá", ou melhor, não por serem "o que os textos querem realmente evidenciar", mas porque dialogam e alimentam estas mesmas inquietações.

50 Para Gadamer, uma obra é, a um tempo, escrita e leitura. Este ponto será mais bem trabalhado mais a frente. 
estas criações respondam a um determinado contexto51 (cultural e histórico) de quem o faz, este "arco", ou "círculo" hermenêutico é que nos orienta a (e à) compreensão. ${ }^{52}$

Atento à hermenêutica de Gadamer e à fragilidade do contextualismo frente às críticas pósestruturalistas, David Harlan segue na proposição de uma nova História Intelectual. Diz ele:

Se nos perguntarmos "o que é uma escrita histórica?", a resposta só pode ser "há este tipo de escrita da história, e este tipo, e então novamente este tipo". Se tal entendimento pudesse alcançar uma aceitação, ainda que relutante, da profissão histórica, poderia ser aberto um espaço no qual um outro tipo de história intelectual pudesse ser escrita. ${ }^{53}$

E este "outro tipo de história intelectual", pretendido por Harlan, seria

uma história que dissesse respeito não a autores mortos, mas a livros vivos, não a um retorno de escritores antigos a seus contextos históricos, não à reconstrução do passado, mas fornecendo um meio crítico pelo qual os trabalhos valiosos do passado possam sobreviver a seu passado - possam sobreviver a seu passado de modo a falarnos sobre nosso presente. (Idem).

Dizer não, portanto, à reconstrução do passado e a um retorno de escritores a seus contextos históricos não significa dizer não à história. A negativa é a uma história que Nietzsche chamou de antiquária, que busca um "saber meramente contemplativo", e que, como diz Ernst Bloch, "se refere forçosamente ao que já está concluído e já passou, não tem meios diante de coisas presentes e é cego para o futuro".54 Trata-se, pois, de ver vida no que supostamente estaria morto, ou teria potencial contextual para assim estar. Como disse J. A. Vasconcelos, não se quer "desenterrar tudo o que já não vive mais, mas encontrar no passado elementos que possam abrir perspectivas para o presente e para o futuro".55

Longe de confundir-se com uma nova versão ciceranesca, magistra vitae, de História, esta orientação, que é acusada de presentismo56, não pretende (e não pode, sob riscos de anacronismo e de pressupor o absurdo vazio) perder de vista, outrossim, o horizonte passado, uma vez que a realidade é realidade histórica, constituída de futuro possível e passado pendente. A crítica ao contextualismo se insere não na rejeição da cultura, da estrutura e/ou dos fatos históricos, mas, pelo contrário, na sua vocação de relegar o discurso do passado à morte e de, assim, reduzir sua capacidade de dizer-nos sobre a condição humana: sobre a vida, a existência e as experiências no mundo.

51 GADAMER, Hans-George. O Problema da Consciência Histórica. Rio de Janeiro: Ed. FGV, 2003, p. 58.

52 "É precisamente 0 que temos em comum com a tradição com a qual nos relacionamos que determina as nossas antecipações e orienta a nossa compreensão". Idem., p. 59. (Grifo do autor).

53 HALAN, David. A História Intelectual e o Retorno da Literatura. In: RAGO, M.; GIMENES, R. Narrar o Passado, Repensar a História. Campinas: Ed. Unicamp, 2000, p. 62.

54 BLOCH, Ernst. O Princípio Esperança. Rio de Janeiro: EdUerj, 2006, vol. 1, p. 196.

55 VASCONCELOS, J. A. História e Pós-estruturalismo. In: RAGO, M.; GIMENES, R. op. cit., p. 120.

56 "Os historiadores de orientação contextual deveriam parar de punir seus colegas por 'presentismo' e reconhecer 0 valor - senão a necessidade - de deixar que o presente interrogue o passado"; "Textos não apontam pra trás, para 0 contexto histórico ou para as intenções putativas de seus autores já mortos: eles apontam para frente, para as possibilidades ocultas do presente". HARLAN, D. op. cit., pp. 61-54. 
"Mas somos nós os coloristas"! Se somos nós, na investida ao passado, que colorimos o quadro do consumado através dos nossos preconceitos e interpretações, somos nós, sujeitos históricos, que desenhamos e pintamos o presente, a realidade em fluxo. Deste modo, tanto quem interpreta quanto a obra interpretada são, como diz Gadamer, históricos; e, mais, são culturais. Interpretação57 e obra são, assim, representações.

A "virada cultural"58, ou, em outros termos, a emergência de uma nova História Cultural, nos possibilita pensar a condição humana de modo bastante diferente daquele proposto pelo materialismo quantitativo e economicista e pela História Social. Se para estes últimos, a cultura é entendida como "um nível da experiência histórica" (o terceiro; sendo a economia e a demografia os outros dois), a nova noção de cultura a apresenta como "determinante básico da realidade". Em Hunt:

as relações econômicas e sociais não são anteriores às culturais, nem as determinam; elas próprias são campos de prática cultural e produção cultural - 0 que não pode ser dedutivamente explicado por referência a uma dimensão extracultural da experiência. 59 .

A "virada", portanto, propõe que antes de ser "condicionada" pelas relações de poder, pela economia e pelas instituições, é a cultura que as constitui, ditando os sentidos e significados, ou seja, as cores, que estes venham a ter para o sujeito e para a sociedade. E podemos - e devemos - ir mais além, pois a cultura se manifesta nas paixões, nos medos, nas pretensões estéticas, morais e religiosas; se manifesta e se constitui, pois, na imaginação criativa e no (e pelo) imaginário social, na linguagem e na Utopia: tanto nas imagens "do melhor" quanto nos desenhos de horizontes futuros. Enfim, ela se manifesta na e pela subjetividade, na e pela ação prática individual, que, a transformando de dentro para fora, não a permite ter o estatuto de estável, acabada, imóvel e se constituir daquela coerência linear que a vontade-de-ordem quer reproduzir e "encontrar".

É-nos cabido, deste modo, superar o dualismo representação x realidade, que se sustenta sobre as rígidas bases de uma realidade entendida como fática e consumada. Repetindo Chartier, já citado, as representações da realidade são componentes da realidade. A realidade social não está "lá fora", portanto, mas, em construção, em permanente vir-a-ser, na relação entre cultura e

57 Em Nietzsche, podemos ler: "Para toda espécie de história não há nenhuma proposição mais importante que aquela que, com tanto esforço, foi conquistada - ou seja, que a causa do surgimento de uma coisa e sua utilidade final, seu emprego e ordenação de fato em um sistema de fins, estão toto coelo, um fora do outro; que algo de existente, algo que de algum modo se instituiu, é sempre interpretado outra vez por uma potência que lhe é superior para novos propósitos, requisitado de modo novo, transformando e transpondo para uma nova utilidade; que todo acontecer no mundo é um sobrepujar, um tornar-se senhor, e que, por sua vez, todo tornar-se senhor é um interpretar de novo modo, um ajustamento, no qual o "sentido" e "fim" de até agora tem de ser necessariamente obscurecido ou inteiramente extinto". NIETZSCHE, F. Para uma Genealogia da Moral. In: ___. Coleção Os Pensadores. São Paulo: Abril Cultural, 1983. 58 Termo empregado por Peter Burke em: BURKE, Peter. O que é História Cultural? Rio de Janeiro: Zahar, 2005, p. 44. 59 HUNT, Lynn. Apresentação. In: (org.). A Nova História Cultural. São Paulo: Martins Fontes, 2001,p. 9. 
indivíduo: tanto na resignação quanto na consciência utópica que, inquieta, a quer ultrapassar.

\section{História, Literatura e Subjetividade}

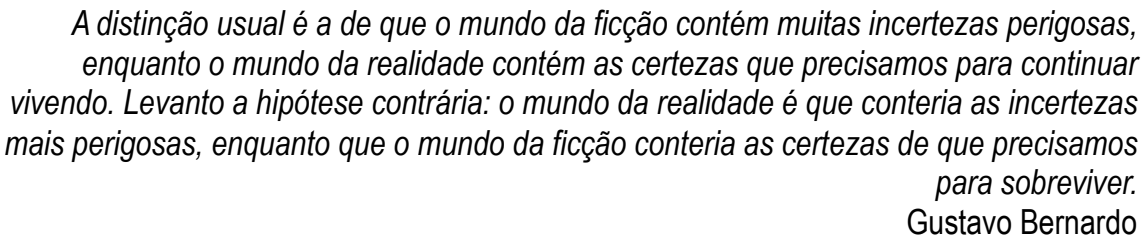

A construção da disciplina histórica como ciência se deu, conforme já tratado, sobre a afirmação da história reveladora da verdade, definida, por contraste, como escrita não-ficcional, enquanto a literatura60 seria a escrita dedicada ao não verdadeiro. No século $X X$, as tradições francesa e materialista aprofundaram esse abismo ao negar a cientificidade das narrativas históricas ancoradas no "relato" dos eventos, o que acabou se transformando numa recusa às narrativas de um modo geral. Caberia, então, à historia ciência ser "contrária à história que diverte e contrária ao romance histórico". ${ }^{61}$ Como escreveu Rancière, "os historiadores da nova escola aprenderam lições da estatística e da demografia (...) os materiais da História deveriam estar ao abrigo das fábulas da opinião e dos torneios dos literatos". (Idem).

A chamada "volta às narrativas"62 ou "retorno da literatura" pela História talvez signifique que, no "embalo" da crise, historiadores têm estado mais sensíveis à fragilidade epistemológica da chamada aporia da verdade que sustenta a sua disciplina. Não que a opção a estudos pautados não nas estruturas, mas nos acontecimentos, crescente nos últimos anos, sejam literalmente uma "volta às narrativas", como sugerem Burke e Stone ${ }^{63}$, justamente porque a História nunca deixou de sê-la. ${ }^{64}$ Mas que a aproximação entre história e literatura não seja mais bloqueada pelas barreiras da suposta cientificidade, e que possa, como propõe Benatte, "colocar a história novamente próxima da bela escrita". Não (somente) para fazer "da história um belo jogo de palavras para satisfazer 0 prazer estético", mas para

radicalizar a crítica da própria noção de verdade com que opera a história, (...) [para]

60 Manteremos aqui a palavra "literatura" para fazer referência às literaturas ficcionais, sem necessária distinção de gêneros, formas, estilos e escolas, embora por vezes sejam e tenham sido empregadas "ficção" e "literatura ficcional" ao longo do trabalho com a mesma intenção.

61 RANCIĖRE, Jacques. Os Nomes da História: um ensaio de poética do saber. São Paulo: EDUC/Pontes, 1994. Apud: BENATTE, Antonio Paulo. História, Ciência, Escritura e Política. In: RAGO, M.; GIMENES, R. Narrar o Passado, Repensar a História. Campinas: Ed. Unicamp, 2000.

62 BURKE, Peter. A Escrita da História. São Paulo: UNESP, 1992.

63 STONE, Lawrence. The Revival of Narrative: reflections of an New Old History. Past \& Present, 1979.

64Falar em "história narrativa" é, como sustentado aqui, um pleonasmo, já que, como afirma Benatte, "esse gênero de discurso chamado História é inseparável da narração escrita. A História nasce como um tipo de escritura, um gênero narrativo em prosa, uma forma de grafia do discurso. Então, nunca houve, simplesmente porque não poderia haver, um abandono da narrativa". 
fazer da história um lugar de acontecimento de linguagem, (...) [e para] politizar crítica e positivamente a própria linguagem e o uso que dela fazemos inevitavelmente para presentificar o passado. (p. 96).

Se é um momento propício para a revisão de pressupostos que sustentaram a história na sua fase moderna, que seja, semelhantemente, fértil para que antigas restrições para/com a literatura ficcional - ou beletrista -, cultivados pelos historiadores há cerca de dois séculos, sejam revistas e questionadas. Pois parte da rejeição que o "retorno da literatura" encontra na historiografia talvez seja, ao lado da angústia provocada pelo questionamento da cientificidade da história, a pressuposição de que a literatura ficcional lide com a mentira, o falseamento e 0 entretenimento, não contribuindo, assim, para os "espíritos estudiosos". Como ironicamente escreveu David Harlan, a literatura seria "algo que se deveria evitar como uma questão de higiene intelectual". 65

Semelhante crítica podemos encontrar em Adorno, quando sustenta que a negação da forma e da aparência estética pelo racionalismo científico guarda consigo o pressuposto de que, quanto menos houver "daquela espontaneidade subjetiva", quanto mais a interpretação puder ser escamoteada, tanto melhor para a objetividade científica. Diz ele, com sua ironia ácida:

Quem interpreta, em vez de simplesmente registrar e classificar, é estigmatizado como alguém que desorienta a inteligência para um devaneio impotente. Ser um homem com os pés no chão ou com a cabeça nas nuvens, eis a alternativa. (...) Para o purismo científico, qualquer impulso expressivo presente na exposição ameaça uma objetividade que supostamente afloraria após a eliminação do sujeito, colocando também em risco a própria integridade do objeto. (...) Na alegria contra as formas, a reflexão sobre as coisas do espírito torna-se privilégio dos desprovidos de espírito. ${ }^{66}$

Dominick LaCapra, contudo, nos faz sugerir que a resistência à literatura talvez não se dê somente pelos dois motivos já apontados. Segundo ele, a História Social67, além de lidar com os textos de modo estreito e utilitário68, estabeleceu certa rejeição àquilo que ela denomina pejorativamente de "alta cultura". A preferência por uma história "de baixo pra cima", ou, como também dito, "vista de baixo" (frutífera nas últimas décadas não só nos Estados Unidos, a propósito da reflexão de LaCapra, mas também no Brasil69), acaba por repudiar a leitura de "textos clássicos",

65 HALAN, David. A História Intelectual e o Retorno da Literatura. In: RAGO, M.; GIMENES, R. Narrar o Passado, Repensar a História. Campinas: Ed. Unicamp, 2000, p. 18.

66 ADORNO, T. W. Notas de Literatura I. São Paulo: Duas Cidades/Editora 34, 2008, pp. 17-19.

67 Reduziremos, aqui, mesmo que um tanto ou quanto grosseiramente, no termo "História Social", as vertentes materialistas e Annales; incluindo, dentre ambos, a tida História Social da Cultura.

68 LaCAPRA, D. Rethinking Intellectual History: texts, contexts and Language. Ithaca: Cornell University Press, 1985, p. 339.

69 A respeito do caso brasileiro, ver ROUANET, Sérgio Paulo. As Razões do lluminismo. São Paulo: Cia. das Letras, 2004. No capítulo "O Novo Irracionalismo Brasileiro", Rouanet diz que a desqualificação da alta cultura parte de uma equivocada indistinção entre "cultura popular" e "cultura de massas" e acaba, em vez de "proteger a cultura popular", "sacralizando a cultura de massas". Mas, diz ele, "o que ameaça a sobrevivência da literatura de cordel não é Finnegan's Wake, e sim a telenovela". Rouanet e LaCapra se aproximam: para o primeiro, este irracionalismo reduz a alta cultura ao título de "elitista", para o segundo: ao rótulo de "burguesa". 
sem se dar conta sequer das dimensões contestatórias que estas leituras podem provocar. ${ }^{70}$ Estabelecendo uma identidade "anti-burguesa", ou "anti-elitista", esta História privilegia os documentos de arquivo e excluiu ou homogeniza as obras literárias e filosóficas. (p. 342). Consequentemente, pauta sua avaliação e juízo mais a partir dos documentos (de preferência que sejam inéditos) que o historiador consegue garimpar e reunir do que a partir dos problemas formulados pelo seu trabalho (p. 92). Privilegia, assim, adverte LaCapra, outra coisa que não a interpretação, a crítica e a capacidade de elaborar reflexões próprias inovadoras.

A emergência da nova História Cultura pode ir, todavia, no contrafluxo desta tradição "do social". Como diz Pesavento:

Clio se aproxima de Calíope. História e Literatura correspondem a narrativas explicativas do real que se renovam no tempo e no espaço, mas que são dotadas de um traço de permanência ancestral: os homens, desde sempre, expressaram pela linguagem 0 mundo do visto e do não-visto, através das suas diferentes formas: a oralidade, a escrita, a imagem, a música. ${ }^{71}$

Uma vez entendendo a literatura como "um discurso privilegiado de acesso ao imaginário das diferentes épocas" (p. 14), e que esta aproximação entre Clio e Calíope não seja impedida nem pelos velhos dualismos nem pela estigmatização da "alta cultura", resta - retomando parte do debate introduzido anteriormente - perguntar não somente sobre "como fazer História", mas "por que fazer História". Pois, mesmo uma "nova" História Cultural pode manter da "velha" História uma relação "estreita e utilitária" com as suas fontes, por mais que não queria encontrar na história causas-e-efeitos, mas significados, por mais que estas fontes não sejam registros cartoriais, mas a imagem, a música, a literatura.

Como a literatura, relato de um poderia ter acontecido, pode servir de traço, rastro, indício, marca de historicidade, fonte, enfim, para algo que aconteceu? A sintonia fina de uma época fornecendo uma leitura do presente da escrita pode ser encontrada em um Balzac ou em um Machado, sem que nos preocupemos com o fato de Capitu ou do Tio Goriot e de Eugène de Rastignac terem existido ou não. (p. 15).

Ampliar a gama de fontes, buscar uma realidade construída e não dada, interessar-se pelos sentidos e significados da experiência individual e social, tudo isso expande os horizontes do fazer História e pode, contudo, manter enferrujado o por que fazer História numa busca por aquele "saber contemplativo" do qual se queixaram Nietzsche e Bloch: se a relação com as Artes, e, com destaque, a Literatura, se guiar não pelo o que ela pode dizer sobre a condição humana, mas a limitar como fonte de conhecimento sobre o passado.

Em outros termos, fazer da literatura fonte histórica - no sentido de contribuir na investigação "do que realmente aconteceu" -, frente à tradição da História Social, com seu

70 LaCAPRA, D. History and Criticism. Ithaca: Cornell University Press, 1985, p. 80.

71PESAVENTO, Sandra J. História e Literatura: uma velha-nova história. In: COSTA, Cléria Botelho da; MACHADO, Maria Clara Tomaz. (orgs.). História e Literatura: identidades e fronteiras. Uberlândia: EDUFU, 2006, pp. 13-14. 
tradicional "fetichismo arquivístico"72, não seja talvez propriamente "limitar", mas, pelo contrário, ampliar. Contudo, se insistimos que a literatura tem como vocação "o discurso sobre o mundo"73, que ela mesma é "pensamento e conhecimento do mundo psíquico e social em que vivemos" e, assim, pode "fazer viver experiências singulares" e "transformar cada um de nós a partir de dentro" (pp. 76-77), buscar nela uma "sintonia fina" para/com uma tal realidade acontecida é praticar, sim, se não um integral reducionismo frente a toda sua capacidade, pelo menos um utilitarismo daltônico perante o colorido do mundo.

Destacamos, deste modo, o interessante depoimento do sociólogo Zigmunt Bauman:

Eu, por exemplo, me lembro de ganhar de Tolstoi, Balzac, Dickens, Dostoievski, Kafka ou Thomas More muito mais insights sobre a substância das experiências humanas do que de centenas de relatórios de pesquisa sociológica. Acima de tudo, aprendi a não perguntar de onde uma ideia vem, mas somente como ela ajuda a iluminar as respostas humanas à sua condição - assunto tanto da sociologia quanto das belles-lettres. ${ }^{74}$

Ora, não nos parece que "perguntar de onde uma ideia vem" seja descartável, ou irrelevante, sobretudo para o historiador, mas que essa indagação não esgote por completo 0 diálogo com o ficcional. Pouco se expande horizontes se a atenção ao texto literário for a mesma que se presta aos documentos de arquivo; ou melhor, se a ambos vai-se imbuído de um mesmo espírito racionalista, que quer ter neles "pistas" para encontrar a tal realidade consumada.

Instrumentalizar a literatura a partir do princípio da utilidade talvez seja uma das piores respostas que um intelectual possa dar não somente à arte, mas ao mundo; sobretudo por se tratar de um mundo "que não gosta da revolta nem da crítica, que acredita plenamente na ordem natural das coisas e que não gosta do acaso, do risco, do engajamento". ${ }^{75}$ Justamente ela, a literatura, tão capaz de nos fazer pensar mundos-outros, e, assim, experienciar realidades distintas do opressivo cotidiano; tão capaz de animar o espírito crítico e a criatividade.

Como diz Todorov, "a literatura amplia o nosso universo, incita-nos a imaginar. (...) Longe de ser um simples entretenimento, uma distração reservada às pessoas educadas, ela permite que cada um responda melhor à sua vocação de ser humano". ${ }^{76}$ Ao instrumentalizar a literatura 0 historiador instrumentaliza a si mesmo e à sua atuação intelectual, pois é este um mundo que

72 LaCAPRA, D. History and Criticism. Ithaca: Cornell University Press, 1985, p. 92. A edição em espanhol de History in Transit emprega o termo "fiebre de archivo" (p. 105). LaCAPRA, D. Historia em Tránsito: experiencia, identidad, teoría crítica. Buenos Aieres: Fondo de Cultura Económica, 2006.

73 "Permanece o fato de que a tendência que se recusa a ver na literatura um discurso sobre o mundo ocupa uma posição dominante no ambiente universitário". TODOROV, Tzvetan. A Literatura em Perigo. Rio de Janeiro: Bertrand Brasil, 2009, p. 40.

74 BAUMAN, Zigmunt. ENTREVISTA concedida a Maria Lúcia Garcia Pallares-Burke. Tempo Social. Revista de Sociologia da USP, v. 16, n. 1, 301-325, jun. 2004, citação p. 319. Disponível em: http://www.scielo.br/scielo.php?pid=S0103-20702004000100015\&script=sci_arttext.

75 SOARES, Jorge Coelho. Em Busca de uma "Razão Sensível" no Reino da Cultura de Massa. Revista Logos: comunicação e universidade. Rio de Janeiro: UERJ, ano 9, n. 17, $2^{\circ}$ semestre de 2002, p. 13.

76 TODOROV, T. A Literatura em Perigo. Rio de Janeiro: Bertrand Brasil, 2009, pp. 23-24. 
"gradativamente se opõe ao 'desejo de Filosofia' e que tende a colocar os filósofos - e, por extensão, os intelectuais de um modo geral -, nas categorias de 'inúteis', posto que nada produzem que possa ser mensurável por uma lógica do cálculo". ${ }^{77}$

Enquanto representação, a obra literária é, decerto, marca de historicidade. Pode-se, através dela, elaborar saberes e estimular reflexões e conhecimentos sobre o passado. Mas se ela aponta para o passado, o seu lugar de origem, aponta também para o presente e para o futuro. Se fora produzida a partir da relação entre indivíduo e cultura, a esta relação ela não se prende, pois, tal qual o filho errante, ela é também vir-a-ser - se nasceu em um tempo, ela não pertence a este tempo: ela não se encerra nele.

Concordamos com Adriana Facina na alegação que se faz preciso "dessacralizar a criação literária", negando um "idealismo que a vê como independente e autônoma em relação às condições materiais da sua produção" ${ }^{78}$ Entretanto,

se o texto literário não puder nos mostrar outros mundos e outras vidas, se a ficção ou a poesia não tiverem mais o poder de enriquecer a vida e o pensamento, então teremos de concordar com Todorov e dizer que, de fato, a literatura está em perigo. ${ }^{79}$

Buscamos superar, pois, os dualismos através das noções de realidade como vir-a-ser, de cultura como transformação, de linguagem como elemento cultural, de obra e interpretação como representações. Mas este duplo caráter da literatura ${ }^{80}$, que não é dual, mas complementar, de representação histórica e de "organismo vivo"81, de ser histórica e meta-histórica, se mantém, pois é justamente a partir desta sua natureza híbrida ${ }^{82}$ que se pode fugir do lugar-comum racionalista do realmente acontecido, do faticamente consumado.

Em outros termos, se concordarmos que - tendo em vista o plano da realidade fática, centrada essencialmente no consumado - a ficção representa também experiências do poderia-ter-

\footnotetext{
77 SOARES, J. C. op. cit.

78 FACINA, Adriana. Literatura e Sociedade. Rio de Janeiro: Zahar, 2004, p. 10.
}

79 MEIRA, Caio. Apresentação à Edição Brasileira. In: TODOROV, T. op. cit., p. 12.

80 Não somente da literatura, mas da filosofia e de demais textos que nos permitam pensar a cultura, a subjetividade, as transformações dos conceitos, e, enfim, as ideias.

81 Organismo vivo, mas não, como diz Todorov, "um objeto de linguagem fechado, auto-suficiente, absoluto". (p. 38). De acordo com Caio Meira, a noção de que a obra literária é um organismo vivo é "uma bela imagem de Henry James". ( $p$. 11).

82 "De qualquer livro, pode-se dizer que é para todos e para ninguém"; Gadamer sustenta que a literatura só se completa na leitura. Escrita e leituras são a "unidade do texto": "a literatura e sua recepção na leitura mostram um grau máximo de desvinculação e mobilidade", tanto que um livro não precisa ser lido de uma só vez, "de modo que o fato de deixá-lo de lado representa uma tarefa própria da retomada, coisa que não possui correlato no escutar ou no contemplar". Assim, diz Gadamer, a leitura é também representação. Em vez de "re-produção", a leitura "pertence essencialmente à obra de arte literária". Nesta passagem há talvez um resumo do que queremos dizer com natureza dupla: "O conceito de literatura não deixa de estar vinculado ao seu receptor. A existência da literatura não é a sobrevivência morta de um ser alienado, que se desse simultaneamente à realidade vivencial de uma época posterior. $A$ literatura é, antes, uma função da preservação e da transmissão espiritual e traz, por isso, a cada situação presente, a história que nele se oculta". GADAMER, H-G. Verdade e Método I. Petrópolis, Ed. Vozes, 1999, pp. 256-257-258. 
acontecido, 83 este caráter pendente do texto ficcional, em vez de marginalizado ou reduzido na procura de uma "sintonia fina" para/com uma época/cultura, poderia ser explorado em outras dimensões, sobretudo, existenciais.

Se pensarmos nas literaturas utópicas (eutópicas e distópicas), nas ficções científicas, nas artes surrealistas e nas estórias fantásticas, sobretudo, a questão mimética destas criações ficcionais afronta decisivamente a homogenização ingênua, de modo a suspender a afirmação de que a ficção quer oferecer "uma imagem verbal da realidade" até que se questione qual realidade. Um outro tipo de mímese se faz presente nestes textos. Ou melhor, outros tipos. Apostando no estranhamento, no espantamento, no afrontamento à lógica, à "realidade dos fatos", à naturalização dos valores e das verdades, estes poderiam-ter-acontecido se potencializam ainda mais, abrindo caminhos outros a possibilidades outras (possíveis futuros, possíveis realidades), talvez até mesmo paradoxais.

Um desafio, pois, de difícil (se não impossível, improvável) mensuração a uma abordagem que estigmatize e despreze a subjetividade, e que busque nas representações ficcionais acesso não aos dilemas, às contradições, às angustias, aos medos e paixões que atravessam e constituem a existência humana, mas ao que realmente aconteceu.

Aproximações da História com a Filosofia, com a Psicologia e com as Artes, não para capturar e incorporar respostas prontas, mas para compartilhar perguntas e inquietações, pode vir a constituir um "campo" de saber fértil para a nova historiografia nascente. 0 interesse crescente por uma nova História Cultural84, com vocação a não se interessar pelos "mecanismos que regulam, fora de qualquer controle subjetivo, as relações sociais, e mas sim [pelas] racionalidades"85. Capaz, portanto, de ampliar a crítica que quer compreender "como vivem os indivíduos na sociedade" para lançar a questão "como vive a sociedade nos indivíduos", aponta um caminho que pode ser frutífero para novas reflexões sobre o que pode a História. Pois a História, como diz Hayden White,

pode desafiar o mundo a cada segundo, pois somente ela serve de mediadora entre 0 que é e o que os homens acham que deveria ser, exercendo um efeito verdadeiramente humanizador. Mas a história só pode servir para humanizar a experiência se permanecer sensivel ao mundo mais geral do pensamento e da ação do qual procede e ao qual

83 Em passagem já citada, Pesavento apresenta a ficção como "poderia ter sido" (p. 15). Aqui, ela a trata como "nãoacontecido": "O que vemos hoje, nesta nossa contemporaneidade, são historiadores que trabalham com o imaginário e que discutem não só o uso da literatura como acesso privilegiado ao passado - logo, tomando o não-acontecido para recuperar o que aconteceu - como colocam em pauta a discussão do próprio caráter da história como uma forma de literatura". PESAVENTO, S. História e Literatura: uma velha-nova história. In: COSTA, Cléria Botelho da; MACHADO, Maria Clara Tomaz. (orgs.). História e Literatura: identidades e fronteiras. Uberlândia: EDUFU, 2006, p. 14. (Grifo da autora).

84 Para Pesavento, a História Cultural seria "o novo perfil de Clio". PESAVENTO, Sandra J. História e História Cultural. Belo Horizonte: Ed. Autêntica, 2008, p. 7.

85 CHARTIER, Roger. A História Hoje: dúvidas, desafios, propostas. Estudos Históricos, Rio de Janeiro, vol. 7, n. 13, 1994, p. 98. 
retorna. 86

Se, como sustentado, a Literatura não puder enriquecer a vida e o pensamento, estará ela definitivamente em perigo, a História, se permanecer insensível ao mundo do pensamento e da ação, se continuar se recusando a "usar os olhos que a arte lhe pode dar, haverá de permanecer cega - cidadã de um mundo em que 'as pálidas sombras da memória em vão se debatem com a vida e com a liberdade do tempo presente'".(Idem).

\section{Referências Bibliográficas}

1. ADORNO, Theodor W. Notas de Literatura I. São Paulo: Duas Cidades/Editora 34, 2008.

2. BAUMAN, Zigmunt. ENTREVISTA concedida a Maria Lúcia Garcia Pallares-Burke. Tempo Social. Revista de Sociologia da USP, v. 16, n. 1, jun. 2004, pp. 301-325.

3. BENATTE, Antonio Paulo. História, Ciência, Escritura e Política. In: RAGO, Margareth; GIMENES, Renato. Narrar o Passado, Repensar a História. Campinas: Ed. Unicamp, 2000, pp. 63-103.

4. BERGER, Peter; LUCKMANN, Thomas. Modernidade, Pluralismo e Crise de Sentido: a orientação do homem moderno. Petrópolis: Ed. Vozes, 2005.

5. BLOCH, Ernst. O Princípio Esperança. Vol. 1. Rio de Janeiro: EdUerj, 2006.

6. BURKE, Peter. A Escrita da História. São Paulo: UNESP, 1992.

7. O que é História Cultural? Rio de Janeiro: Zahar, 2005.

8. CALDERA, Alejandro Serrano. Filosofia e Crise: pela filosofia latino-americana. Petrópolis: Ed. Vozes, 1984.

9. CARVALHO, José Murilo. História Intelectual no Brasil: a retórica como chave de leitura. Revista Topoi, Rio de Janeiro, n.1, pp. 123-152.

10. CERTEAU, Michel de. A Escrita da História. Rio de Janeiro: Forense Universitária, 1982.

11. CHARTIER, Roger. A História Cultural: entre práticas e representações. Lisboa: Difel; Rio de Janeiro: Bertand Brasil, 1988.

12. . História Hoje: dúvidas, desafios propostas. Revista Estudos Históricos, Rio de Janeiro, vol. 7, n.

13. . O Mundo como Representação. Revista Estudos Avançados. 11 (5), 1991, pp. 172-191.

14. FACINA, Adriana. Literatura e Sociedade. Rio de Janeiro: Zahar, 2004.

15. GADAMER, Hans-George. O Problema da Consciência Histórica. Rio de Janeiro: Ed. FGV, 1999.

16. Verdade e método. Petrópolis, vol.1, Ed. Vozes, 2002.

17. GEARY, Dick. A "Virada Linguística", Pós-Modernismo e História do Trabalho. Revista Perspectiva. Florianópolis, v.18, n.33, pp. 35-63, jan.jjun. 2000.

18. GEERTZ, Clifford. O Saber Local: novos ensaios em antropologia interpretativa. Petrópolis: Ed. Vozes, 2009.

19. GINZBURG, Carlo. O Fio e os Rastros: verdadeiro, falso, fictício. São Paulo: Cia. das Letras, 2007.

86 WHITE, H. Trópicos do Discurso: ensaios sobre a crítica da cultura. São Paulo: Edusp, 2001, p. 63. (Grifo do autor). 
20. GURGEL, Maria Cristina. A Linguagem: história, origem e natureza. In: CARNEIRO, Marísia. (org.). Pistas e Travessias. Rio de Janeiro: Ed. UERJ, 1999, pp. 11-27.

21. HALAN, David. A História Intelectual e o Retorno da Literatura. In: RAGO, M.; GIMENES, R. Narrar o Passado, Repensar a História. Campinas: Ed. Unicamp, 2000, pp. 15-61.

22. HUNT, Lynn (org.). A Nova História Cultural. São Paulo: Martins Fontes, 2001.

23. JENKINS, Keith. A História Repensada. São Paulo: Ed. Contexto, 2007.

24. KRAUSE, Gustavo Bernardo. Ficção e Ceticismo. In: Ed. Annablume, 2005. (org.) Literatura e Ceticismo. Rio de Janeiro:

25. LaCAPRA, Dominick. Historia em Tránsito: experiencia, identidad, teoría crítica. Buenos Aires: Fondo de Cultura Económica, 2006.

26. H_ History and Criticism. Ithaca; London: London: Cornell University Press, 1985.

27. Rethinking Intellectual History: texts, contexts and Language. Ithaca; London: Cornell University Press, 1985

28. LIMA, Luiz Costa. História. Ficção. Literatura. São Paulo: Cia. das Letras, 2006.

29. NEVES, Luiz Felipe Baêta. A Construção do Discurso Científico: implicações sócio-culturais. Rio de Janeiro: Ed. UERJ, 1998.

30. História Intelectual e História da Educação. Revista Brasileira de Educação, vol11, n32, maio/ago.2006.

31. NIETZSCHE, Friedrich W. Coleção Os Pensadores. São Pulo: Abril Cultural, 1983.

32. PESAVENTO, Sandra. História e História Cultural. Belo Horizonte: Ed. Autêntica, 2008.

33. História e Literatura: uma velha-nova história. In: COSTA, Cléria Botelho da; MACHADO, Maria Clara Tomaz. (orgs.). História e Literatura: identidades e fronteiras. Uberlândia: EDUFU, 2006, pp. 11-27.

34. Sensibilidades: escrita e leitura da alma. In: PESAVENTO, S.; LANGUE, F. (orgs.). Sensibilidades na História: memórias singulares e identidades sociais. Porto Alegre: Ed. UFRGS, 2007, pp. 921.

35. Sensibilidade no Tempo, Tempo das Sensibilidades. Nuevo Mundo Mundos Nuevos, $n^{\circ}$ 4, 2004. Disponível em: http://nuevomundo.revues.org/229

36. SAHLINS, Marshall. Cultura na Prática. Rio de Janeiro: Ed. UFRJ, 2004.

37. SOARES, Jorge Coelho. Em Busca de uma "Razão Sensível" no Reino da Cultura de Massa. Revista Logos: comunicação e universidade. Rio de Janeiro: UERJ, ano 9, n. 17, $2^{\circ}$ semestre de 2002.

38. TODOROV, Tzvetan. A Literatura em Perigo. Rio de Janeiro: Bertrand Brasil, 2009.

39. VASCONCELOS, José Antônio. História e Pós-estruturalismo. In: RAGO, M.; GIMENES, R. Narrar o Passado, Repensar a História. Campinas: Ed. Unicamp, 2000, pp. 105-121.

40. WHITE, Hayden. Meta-História: a imaginação histórica no século XIX. São Paulo: Edusp, 1992.

41. Trópicos do Discurso: ensaios sobre a crítica da cultura. São Paulo: Edusp, 2001. 